\title{
Critical Discourse Analysis of Iran-China Relations Through Football Headlines
}

\author{
Rajdeep Singh \\ Correspondence: Rajdeep Singh, Student of Graduate Studies of Linguistics, Payame Noor University, Graduate of \\ European Studies, University of Tehran, Iran.
}

Received: March 14, 2021

Accepted: April 13, 2021

Online Published: May 9, 2021

doi:10.5430/elr.v10n2p1

URL: https://doi.org/10.5430/elr.v10n2p1

\begin{abstract}
Iran and China are getting closer day by day, from economic to political to social relations. Since media plays a significant role in shaping norms, social relations, and values in society, it is not a neutral medium to propagate information only. Social and political elites, as well as political fractions, use media to shape public opinion with the least cost. Therefore, this paper attempts to answer the question as to which ideologies, social and political thoughts Iranian football headline-writers attempt to convey to the wider public in Iran. To answer this question the main hypothesis of the paper posits that Iranian political and social elites are conveying a much more economic dimension of China, downplaying the political dimension of China, including the mounting political oppression inside China and Hong Kong, and the dramatic situation of Chinese Muslims. This paper approaches the abovementioned question under the framework of critical discourse analysis proposed by Norman Fairclough (1989). With regards to the methodology of the paper, a qualitative approach has been adopted, availing itself of different headlines of Iranian sport. Findings of the paper indicate that elites in Iran are proposing to the public a much rosier image of china due to closer political and economic ties between the two countries.
\end{abstract}

Keywords: critical discourse analysis, fairclough, football, Iran, China politics, ideology, discourse

\section{Introduction}

After US sanctions on Iran and Iran's difficulty to sell oil and develop economic ties with the rest of the world, China has entered Iranian political scenery with a huge impact. From economic cooperation to political support in the United Nations Security Council, China has played a significant role in Iranian politics. While many in Iran see the Sino-Iranian relations with suspicion, Iranian social and political elites have put their bet on China and its current rise as the economic powerhouse of the world. (Park \& Glenn, 2018: 2-4) Relations between the two countries have grown exponentially in recent years and there have been several meetings between leaders of both countries. On the political front, Chinese officials have praised Iranian efforts to seek stability in the region, while condemning US sanctions on Iran, calling them "illegal"; while the Chinese foreign ministry spokesperson Geng Shuang regarding American sanctions on Iran says that China will continue work with Iran and that "China's bilateral cooperation with Iran is in accordance with the law". (Chinese foreign ministry, 2019)

There have been some frictions regarding close ties between China and Saudi Arabia, but so far so good. While the trade and economic ties between the two countries grow, there has been some uneasiness in Iran regarding the plight of Muslims in China. (Jin, 2016: 108-110) However, Iran has not raised the issue so far, despite having the protection of Muslims' rights as one of its most important foreign policy pillars. The silence of Iranian officials regarding the Xinjiang Muslims has been interpreted by some as the price necessary to pay for better ties with China. In fact, Iran has not been a big exception, and many Muslim countries refrained from criticizing China on human rights, including the bad treatment of Chinese Muslims, not wanting to provoke Chinese reactions, and probably losing a big market share in China. (Kelemen \& Turcsanyi, 2019)

Setting the political background, we look to Sino-Iranian ties from the perspective of newspaper writers. The Reason that football headlines are chosen in this paper is the great readership of football newspapers in Iran. كريمى) Based on estimates, Iranians prefer sports events and are more interested to spend their time reading football news than political ones. Furthermore, the big enthusiasm that sports events provoke on Iranian youth is not a mystery, where big street celebrations after big victories in sports events have been pretty the norm 
than the exception and have affected the youth post-revolution. (روزى كه تا صدسال ديكر براى اير انيان خاص است1, 1393)

Furthermore, no sport has triggered more joy rallies in the streets of Tehran than football. Therefore, newspaper headlines regarding the football match between Iranian and Chinese national teams from the most important sport newspapers were chosen. In the continuation, before analyzing the newspaper headlines, we will briefly discuss some important features of the chosen framework in this paper, i.e. Fairclough's critical discourse analysis.

\section{Critical Discourse Analysis}

While language has an important role to play when it comes to shaping public opinion, its role has been ignored for long before scholars such as Michel Foucault and Fairclough give it the due attention. Foucauldian discourse analysis is an important basis in terms of conceptual architectures and semantic fields; and critical discourse analysis, which Fairclough developed, sheds light "in clarifying how discursive selectivity operates in terms of its lexical, semantic, and pragmatic features and their relation to modes of expression, forms of discourse, genre chains, framing, and so forth". (Sum, 2015, p.50)

First, it's of paramount importance to explain what discourse is meant here. There are two main approaches to the definition of discourse; formalist group defines discourse as a particular unit of language, above the sentence, focusing on the form language takes. Therefore, they treat language as a system of systems, having varying types of structures and organizations themselves. The other group, functionalists, put emphasis on language in use, with all social and historical relations that exist in language, making discourse a unit of social phenomenon, instead of a formal linguistic system. (Richardson, 2007, p.24-25)

Discourse is a multidimensional social phenomenon. As Van Dijk states: "It is at the same tune "a linguistic (verbal, grammatical) object (meaningful sequences or words or sentences); an action (such as an assertion or a threat); a form of social interaction (like a conversation), a social practice; a mental representation, a meaning, a mental model, an opinion, knowledge" (Van Dijk, 2009, p. 67) Discourse is, in fact, a multidimensional social phenomenon. Fairclough describes discourse as a category for designating particular ways of representing particular aspects of social life which includes problems of inequality, disadvantage, poverty, social exclusion in different ways. Therefore, the category of discourse in this sense is defined through its relation to and difference from two other categories, genre, and style. (Fairclough, 2012, p.453)

Discourse is an important tool to hunt language and analyze its meanings and categorize its content. (عضدانلو، 1380) Discourse analysis can be applied to political discourse as well. Specifically interesting for political discourse analysis is then that many of the political actions or practices are at the same time discursive practices. In other words, forms of text and talk in such cases have political functions and implications. (Van Dijk, 1993)

While the critical analysis may seem similar to cultural studies, insisting on the context and social relations, the important difference lies in the emphasis that Discourse critical Analysis puts on fine-grained details and analysis of discursive manipulation. (Huckin, 2002: 4) On the other hand, while reading the text, there is no direct interaction between interpreters and producers, being a heavily one-sided interaction in many respects, non-the-less meanings need to be negotiated between sender and receiver, and this 'dialogic' principle in non-face-to-face interaction is widely recognized. (Simpson, 1993: 112)

Critical discourse analysis, therefore, does not limit itself to linguistic and sentence level analysis; rather it goes much deeper, analyzing the way social forces form and shape discourse and search for hidden discovery through linguistic analysis of the hidden connections among language, power, and ideology. Indeed, we see language as a social system, i.e. a social semiotic. Language is seen as an open system of signs where different interests, parties, opinions, and ideologies are reflected in terms of linguistic units; therefore, language is not neutral but biased towards power and dominant social forces.

\subsection{Discourse Analysis Stages and Procedure}

Discourse is not a reflection of reality, divorced from socio-political connotations, but it emerges from a socio-political environment, affected heavily by social norms and values of the dominant social elites. In fact, Fairclough sees discourse as a tool in hands of the dominant social elite to serve their interests and to lead the subordinate groups. In fact, "Power, ideologies and context play significant roles in the selection of linguistic devices." (Shah, Shabir \& Bilal, 2018, p.495) There is no need to wage a war against other social groups to attain the goals, but rather to shape the discourse around the subaltern groups and co-opt them in the bigger hegemonic social elite. Discourse is indeed a social practice where words, sentences, structures of language are its products. Discourse

1 The day that after a century will remain special, 2013 
is a social process of creating, maintaining, and reproducing the norms, values, and goals of the dominant social group. Therefore, what critical discourse analysts want is not just to describe language as per units and structures. Rather, they want to contribute to society by bringing forth the hidden ideologies, values, and norms that the hegemonic forces are imposing on society which is unaware of the process. (Singh, 2019)

Critical discourse analysts are not interested to maintain the status quo rather they want to change it for the better. Therefore, interpretation of surface structures, meanings of utterances, local coherence of text (cohesion), and different schemas used in the text is a powerful tool in hands of CD analysts to discover and show hidden agendas, ideology, and goals of the text writers. Critical discourse analysis consists of three stages of analysis: description, interpretation, and explanation. The description stage limits itself to identifying and describing particular elements of vocabulary, syntax, and text structure that are ideologically loaded and function ideologically in the text. Power in discourse itself has three forms: power over content: what is to be said; power over relations among different social groups; power over subjects: different roles individuals and social groups have to play in the state set by dominant discourse producer. (Fairclough, 1989, p. 266) Furthermore, language is the vehicle of thought provocation and consensus gathering, where different religious and cultural elements are expressed through words and semantics. (Singh, 2018)

At the interpretative stage, analysts undertake the interpretation of what is hinted at or worded in the text, going beyond mere grammatical and semantic descriptions, focusing on different roles are assigned to different categories of people and individuals in the discourse; though in practice frontier between descriptive and interpretative stages is blurred, subject to the discretion of analysts. Broader societal and institutional aspects of discourse are dealt with at the explanatory stage, which concerns putting the discourse in its special historical, social context, and the overall political-social structure of the society. On the other hand, diagnostic readings and analysis can turn out to be as well ideologically motivated and "that the analyst has a political stance which informs their particular interpretation...writing about ideology does not automatically mean release from ideology." (Simpson, 1993: 107)

Critical discourse analysts and readers have different functions. While the first attempting to identify the ideological themes that run through texts as well as interests of text producers, the persuasion of readers by argumentation should be analyzed as well. (Hucking, 2002: 12)

\section{1- CD Analysis of Selected Football Headlines}

\section{Sport headlines}

1) عبور از ديو ار جين

Crossing the Great Wall of China

2) ديوارجينى

Masonry

3) اززدهاى جينى حريف يوز اير انى نمىشود

Chinese dragon can't compete with Iranian cheetah

4) نبرد دو امبِراتورى

The battle of two empires

5) ملهل يوز ها به روباه و ازدها

The attack of cheetah on fox and dragon

6) جين را بر جين

Annihilate China

7)

Wall to wall

8) جينى شكست

9) Porcelain broke

We begin the analysis of the abovementioned headlines at the descriptive stage. We see how headlines have used semantic relations to highlight different points for readers in an interesting way. The first headline avails itself of different semantic relations. There exists Antonymy between crossing (عبور) and the wall (ديورار). Also, there is a collocation between the wall and china. In headline (2), chidan (جيدن) has polysemy; one meaning is related to 
putting in place something, while the other relates to removing something. Again there is a collocation between China and Wall. There is also an irony as here building the wall (ديوارجينى) is used to say "removing the wall".

In (3), dragon and cheetah are coordinate terms since they share the hypernym of animals. Also, there are collation between China and Dragon and rhyming prose between Irani (Iranian) and Chini (Chinese). In (4), nabard (battle) has polysemy: one is the battle of armies and the other meaning is a sports match. Also, the term Empires is a metonymy of Iran and China. There is a collocation also between empires and battle.

In (5), cheetah and dragon are metaphors for Iranian and Chinese teams. Attack (حملة) has polysemy of attack in the war and attack in a football match. Cheetah, dragon, and fox are coordinate terms, sharing the same hypernymy (animals). There is also rhyming prose between yuzha (cheetah) and ezhdeha (dragon). In (6), there is rhyming prose between chin (China) and barchin (remove).

In (7), there is rhyming prose between two walls (ديوار) and alliteration beginning with a series of words having a wall in them. Also, the wall is a metonymy of the Great Wall of China. In (8), chini (جينى) has polysemy: Chinese and porcelain. Shekast (شكست), which is the verb to break, has polysemy: losing a match and breaking something. Also, there is a collocation between chini (porcelain) and shekastan (شكستن: to break).

We will now proceed to pars syntactic structures of sentences used in headlines as it is shown in table 1.

Table1. Syntactic and discourse parsing

\begin{tabular}{llll}
\hline $\begin{array}{l}\text { Sentence } \\
\text { number }\end{array}$ & Headline & Syntactic parsing & Discourse parsing \\
\hline 3 & $\begin{array}{l}\text { Chinese dragon } \\
\text { can't compete with } \\
\text { Iranian cheetah }\end{array}$ & $\begin{array}{l}\text { Subject as Agent } \\
\text { Intransitive verb } \\
\text { Present tense }\end{array}$ & $\begin{array}{l}\text { The theme in the first part of the } \\
\text { sentence } \\
\text { Rheme at the end of the sentence }\end{array}$ \\
6 & Annihilate china & $\begin{array}{l}\text { Imperative } \\
\text { Transitive verb } \\
\text { Object as patient } \\
\text { Subject is patient } \\
\text { Middle verb }\end{array}$ & $\begin{array}{l}\text { Theme in the first part of the sentence } \\
\text { Rheme at the end of the sentence }\end{array}$ \\
& Porcelain broke & $\begin{array}{l}\text { Theme in the first part of the sentence } \\
\text { Rheme at the end of the sentence }\end{array}$ \\
& &
\end{tabular}

As it is illustrated in table1, sentences are well-formed and they use different grammatical structures to highlight and emphasize the points they make. Now we will begin the interpretative and explanative stage where we attempt to expand the meaning beyond the text, connecting the text with wider society and all the norms, values, and ideologies that writers had when they touched upon the football match between Iran's and China's national football teams. To simplify things, we will blend the abovementioned stages and analyze them in one go. 


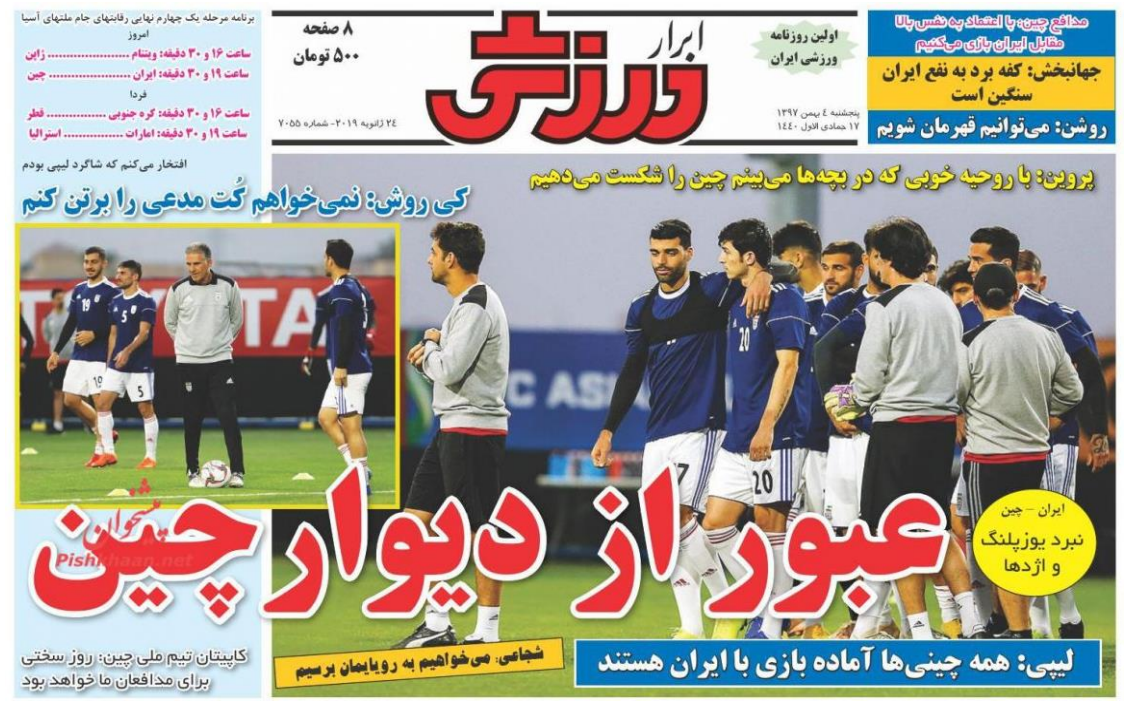

Figure1. Crossing the Great Wall of China

We begin with the analysis of the first headline, considering Figure1 which illustrates the image of the first headline. The Great Wall of China would in the first instance identify China and its great wall; however, the concept of imperial imposition of China and the difficulty to understand the Chinese political and social environment also comes to the imagination of readers. On the other hand, the writer emphasizes the hope to surpass this apparently insurmountable obstacle, pointing out the political and economic imposition of Chinese politics on Iranian elites and government which seems hard to surmount.

Furthermore, the headline is written in red color, which is the color symbolizing China, and it seems the writer wants to hint at the hegemonic force China applies everywhere, including on its people. However, the second meaning of red color, in Iranian imaginary, is of the angry mood and unease which shows that the writer conveys the frustration of Iranians with the hard politics and meddling of China in Iran.

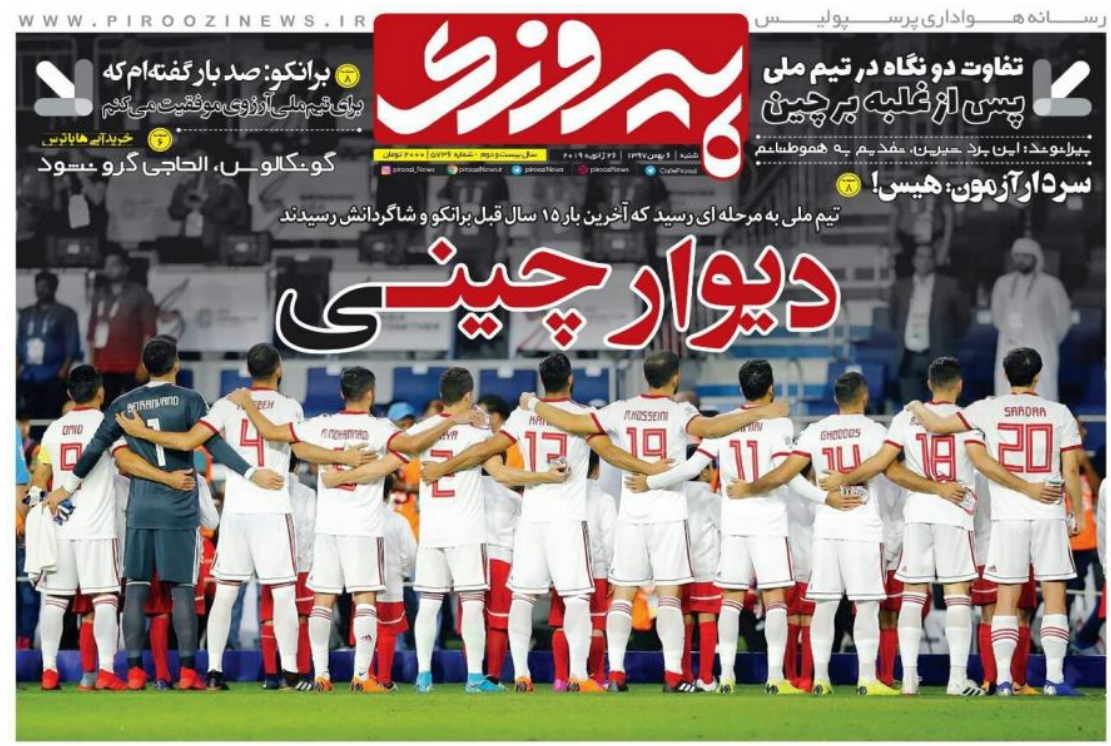

Figure2. Masonry and building of wall

Headline (2) is illustrated in figure2. (روزنامه يِيروزى2، 1397) the analysis is as following: Here, ديوارجينى (masonry) is used which is a metaphor of succeeding to build the bridge to get to the semifinals after having won over China. However, it also the photo on the headline shows a group of players getting together and making a circle, which

\footnotetext{
1 Abrar e varzeshi, 2018

2 Piroozi newspaper, 2018
} 
makes the point that if Iran, both people, and government, get together, they can surmount the insurmountable obstacle of Chinese imposition on Iran. The writer hints at the importance of uniting people and government against any imposition, however big the challenge is.

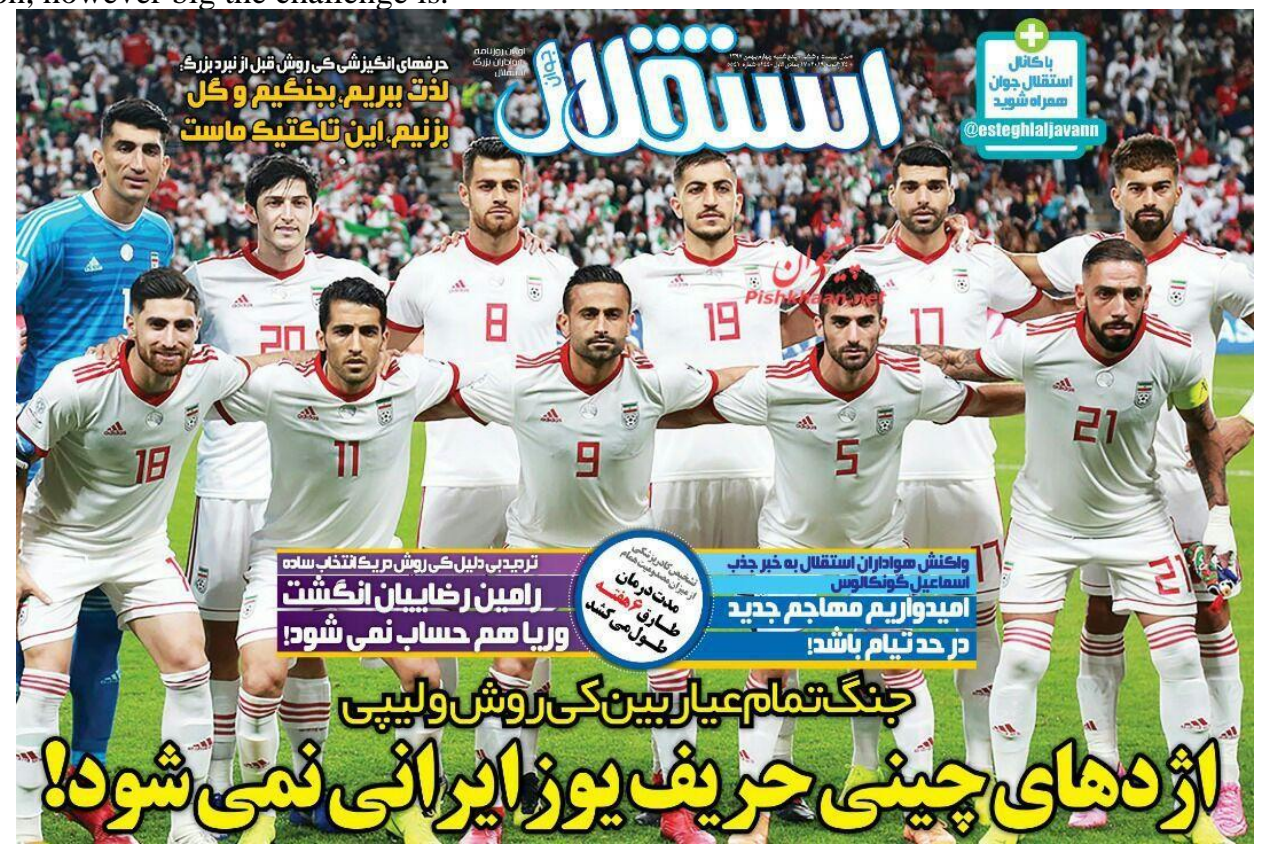

Figure3. Chinese dragon can't compete with Iranian cheetah

Headline (3) reads as Chinese dragon can’t compete with Iranian cheetah and is illustrated in figure3. (روزنامه استقلال، 1397) Here, the Chinese dragon is contrasted with the Iranian cheetah and in this competition, the writer believes that Iran has better chances. Chinese dragon is a metaphor for Chinese industrial prowess and economic supremacy in the world, especially in Iran.

The writer uses irony, as she puts on paper the fact that Iran and China are not comparable, hinting at the fact that Iran is way ahead. However, the writer also acknowledges that it is not a fair competition, one between the Iranian industry and the other, much bigger Chinese economic giant.

\footnotetext{
${ }^{1}$ Esteghlal newspaper, 2018
} 


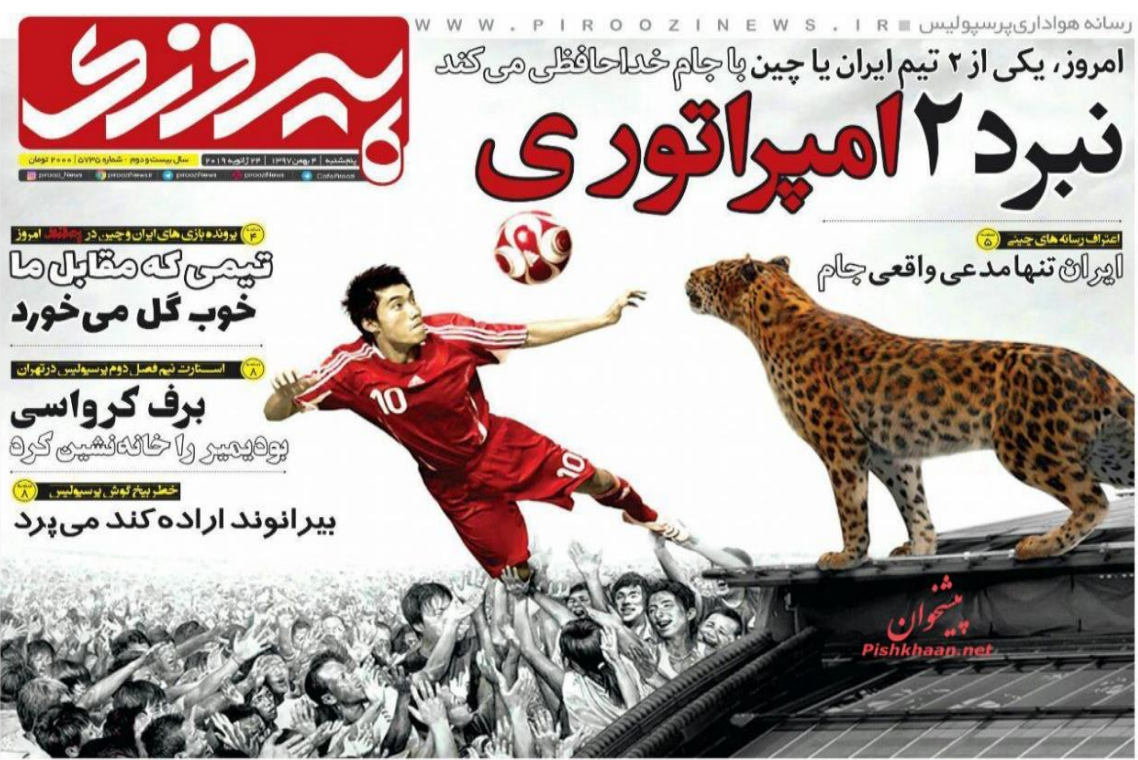

Figure 4 . The battle of two empires

Headline (4) reads as the battle of two empires and is illustrated in figure4. (روزنامه بيروزى1، 1397) in this headline, the writer illustrates Iran with the cheetah, and China with a player supported by Chinese fans. The writer makes his point that China is supported fully by the international community, no matter however undemocratic it be, while Iran is isolated, under heavy US sanctions, somehow injured, and can't move. Indeed, the writer shows the cheetah, which symbolizes fast movements, not in the run mood, but still standing, which is a metaphor of an Iran under sanctions, unable to move, while China is free and run easily to achieve its goals.

Again, the writer plays with colors as well, putting the battle in black - which is a symbol of sadness in Iranian imaginary - and putting the empires in red - which is a symbol of China and also anger and fierceness. The writer, therefore, paints a sad battle of unequal rivalries, where the two countries are dominated by one, China, and its fierce politics.

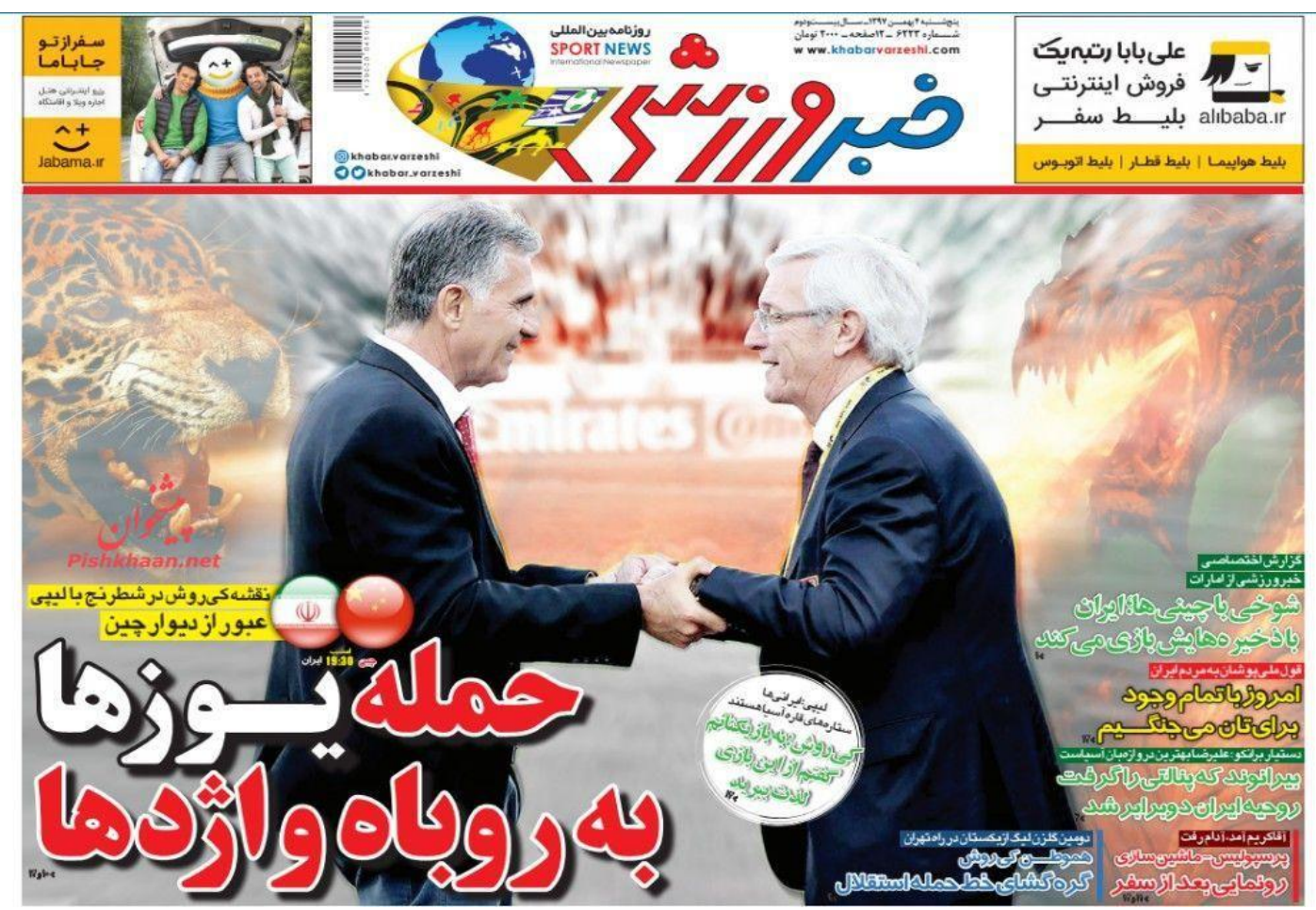

Figure 5. The attack of cheetah on fox and dragon

1 Piroozi newspaper, 2018 
Headline (5) reads as the attack of cheetah on fox and dragon and is illustrated in figure4. (خبرورزشى1، 1398) The writer, here, unite the dragon - metaphor of China - with fox, the metaphor of deceitfulness in Iranian imaginary. In fact, the writer wants to show the connection between China and dirt politics played by it, where deceiving seems connected to fake and low quality made in China products. Furthermore, the writer uses the red color for the attack, as well as China and fox, which is a point that this political match is already done with China attacking and gaining a big share of the market in Iran.

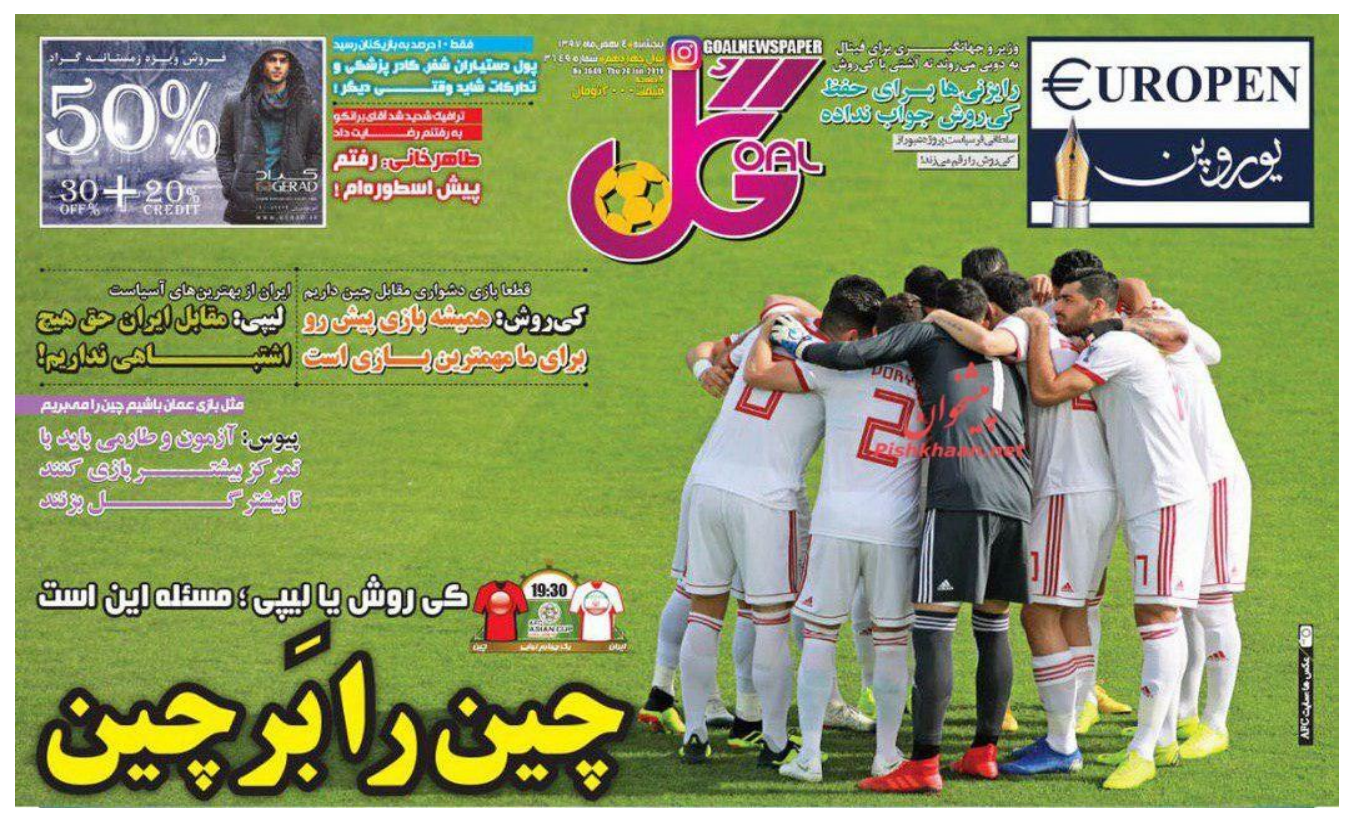

Figure 6. Annihilate China

Headline (6) reads as Annihilate China and is illustrated in figure6. (روزنامه كل2، 1397) writer in this headline brings forth a request as to removing China from the Iranian political and economic scene, desiring a change of direction in the Iranian political scene. The writer, furthermore, chooses the yellow color to make his point; the yellow color symbolizes the frustration and hatred in the Iranian collective imagination, pointing directly to the actions of China in Xinjiang and the plight of Chinese Muslims.

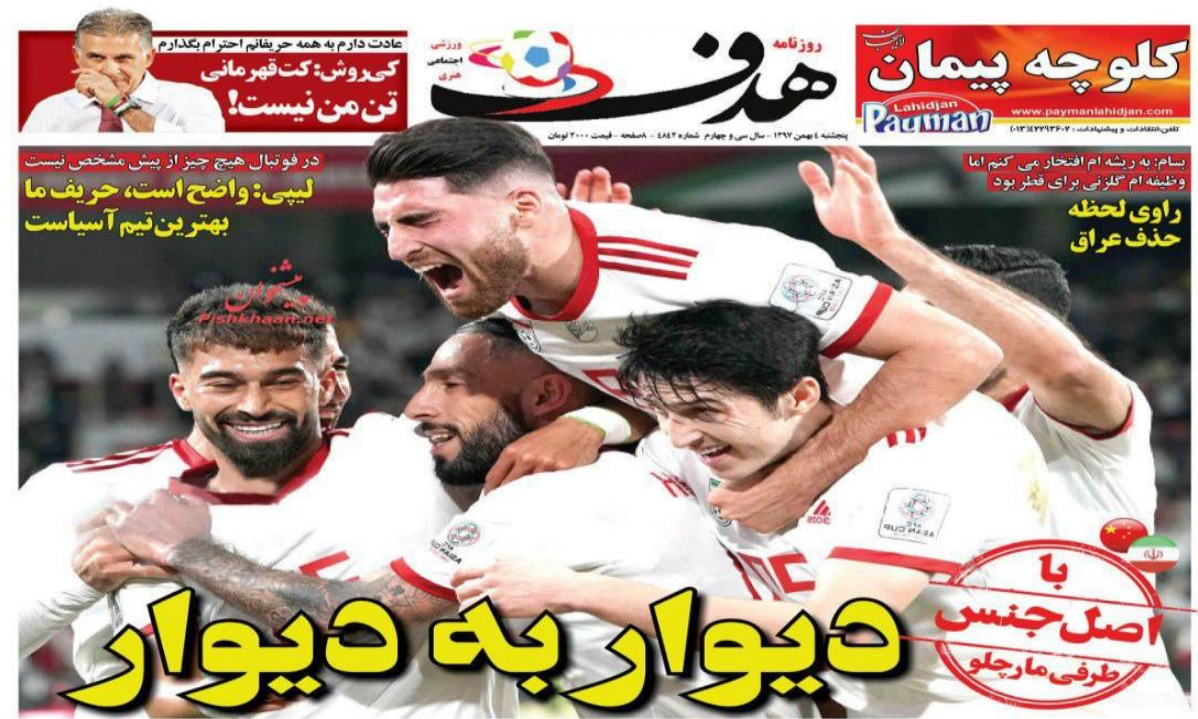

Figure 7. Wall to wall

1 Khabar e varzeshi newspaper, 2018

2 Gol newspaper, 2018 
Headline (7) reads as Wall to the wall and is illustrated in figure7. (روزنامه هدف1، 1397) in this headline, the writer sees the building of the wall- a metaphor for economic protectionism - as the only solution to the economic hegemony of China. However, she paints the headline with yellow, which symbolizes hatred in Iranian culture, pointing out that this type of protectionism is not going to be desired by Iranians and probably would not solve the issue in the long term. In a subsection of the headline, we see the sentence "with original quality" as a gift to China; the writer, therefore, brings forth the general complaint about low-quality Chinese products and uses irony to make her point.
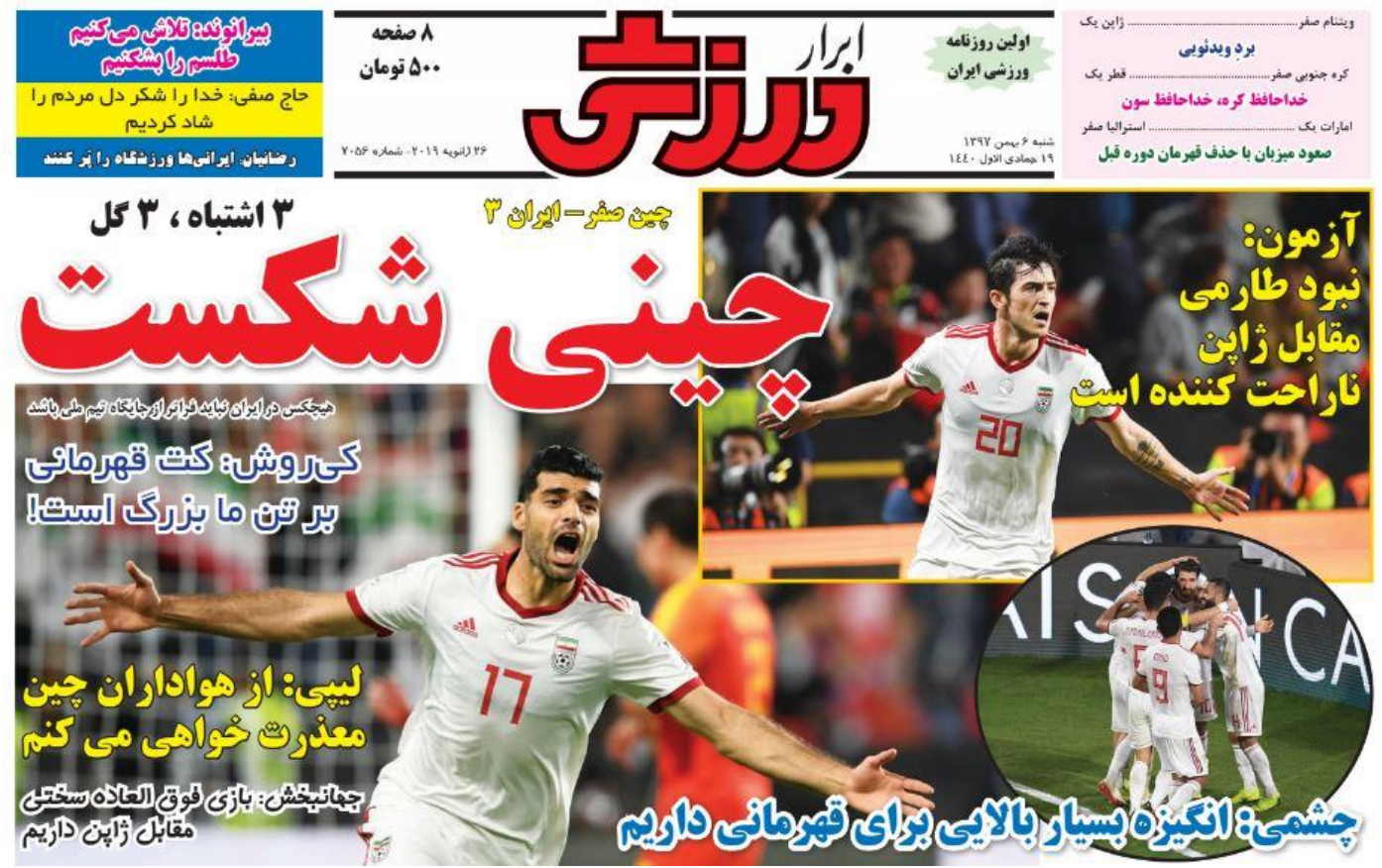

Figure 8. Porcelain is broken

Headline (8) reads as porcelain is broken and is illustrated in figure8. Here, the writer expresses the hope that the Chinese system and political government are so fragile that can be broken with a bit of chance. The writer chooses the color red to illustrate the headline - symbol of China and the Communist Party of China - expressing this way a notion that China, no matter how strong it be, will remain fragile and this fragility is inherent to the Chinese political system.

\section{Conclusion}

Language is not just a medium to communicate and convey information, but also an important medium to produce, reproduce, and main norms, values, and hegemony. Therefore, in this paper, the authors attempt to go beyond the simple reading of words, searching for inner meanings and ideologies of the headline writers. Short space being assigned to deliver their messages, headlines impressively affect the public due to the ease and lightness of task for readers; impressive headlines free the readers from having to go through all the content. As a result of this short space delivery system, headline writers have to use many linguistic tools such as figures of speech or semantic relations - including antonymy, hypernymy, metonymy, metaphor, correlations, and correlated terms - to make their message short but meaningful and ideologically loaded. In the 8 headlines that we analyzed, the ideologies and beliefs of writers were discovered and brought forth. An important feature was the economic dominance of China and low-quality Chinese products. Writers expressed their dismay and even despair in front of a rising giant, China, which, on their opinion, has put chains on Iran's economy. Simultaneously, they build a negative image of China in the Iranian broader public connecting the notion of stronger ties with China to the submission of Iranian might and past glory. Some writers characterize Iran as weak and under heavy sanctions, unable to run and grow. In fact, we see a strong tendency to relate the match between Iran and China national football teams to the economic sphere, playing with notions of product quality, economic protectionism, etc. The paper brings forth the hidden ideologies and meanings through the use of language in football headlines, showing how economic and political ideas and formed

1 Hadaf newspaper, 2018 
ideologies dominate the otherwise friendly environment of a sporting event - a football match - between Iran and China.

\section{References}

Chinese foreign ministry (2019). Chinese spokesman, Geng Shuang, stated "China's bilateral cooperation with Iran is in accordance with the law. Retrieved 2019, February 29th from https://www.fmprc.gov.cn/mfa_eng/xwfw_665399/s2510_665401/2511_665403/t1639169.shtml

Huckin, T. (2002). Critical discourse analysis and the discourse of condescension. In E. Barton \& G. Stygall (Eds.), Discourse studies in composition (155-183). Hampton, NJ: Hampton Press. Retrieved from http://www.writing.ucsb.edu/wrconf08/Pdf_Articles/Huckin_Article.pdf

Jin, W. (2016). Selective Engagement: China's Middle East Policy after the Arab Spring. Strategic assessment, retrieved from https://www.inss.org.il/he/wp-content/uploads/sites/2/systemfiles/SystemFiles/INSS.StrAss19.2.July 16.08Jin.pd f

Park, J. S., \& Glenn, C. (2018). Iran and China. The United States Institute for Peace. Accessed Jan 1, 2018. http://iranprimer.usip.org/ resource/iran-and-china

Richardson, J. E. (2006). Analyzing Newspapers: An Approach from Critical Discourse Analysis. Basingstoke: Palgrave Macmillan. https://doi.org/10.1007/978-0-230-20968-8_7

Shah, K., Shabir, N., \& Bilal, M. (2018). Marginalysing the marginalized: borrowing of the cpec discourse by political agents from political elite. Al-Qalam, 23(2), 476-497. Retrieved from http://journal.alqalamjournalpu.com/index.php/Al-Qalam/article/view/583

Simpson, Paul. 1993. Language, ideology, and point of view. London: Routledge. https://doi.org/10.4324/9780203312612

Singh, R. (2018). A Cognitive Approach to the Semantics in the Sacred Context: Semantic and Symbolic Function of Sacred Words. English Linguistics Research, 7(3). https://doi.org/10.5430/elr.v7n3p1

Singh, R. (2018). Albanian World-View: Co-Locativity as the Schematic Meaning of Albanian Verbal Prefix Bashke. English Linguistics Research, 7(4). https://doi.org/10.5430/elr.v7n4p36

Singh, R. (2018). Areas of errors and difficulty for persian learners of spanish caused by the sound system differences between persian and spanish: a phonetic approach to inter-lingual system. KAAV international journal of English, literature, and linguistics, 5, 1-8. Retrieved from http://www.kaavpublications.org/journals/journal-5/abstract/abstract-1996.pdf

Singh, R. (2018). Auxiliary Verbs in Serbo-Croatian, French, Persian, Spanish and English: A Cognitive-Semantic Approach to the Auxiliary Verb Usage and Passive Voice. English Linguistics Research, 7(3). https://doi.org/10.5430/elr.v7n3p34

Singh, R. (2018). Christian And Sikh Communities In Iran And Role Of Language Identity: A Comparative Approach To The Social-Linguistic Aspects Of The Christianity And Sikhism In The Middle East. Sikh Research Journal, 3(1).

Singh, R. (2018). Derivational Grammar Model and Basket Verb: A Novel Approach to the Inflectional Phrase in the Generative Grammar and Cognitive Processing. English Linguistics Research, 7(2). https://doi.org/10.5430/elr.v7n2p9

Singh, R. (2018). Error Analysis of Persian Learners of Hausa Language: Cognitive Approach to Errors. Journal of Literature, Languages and Linguistics, 45, 10-15. Retrieved from https://iiste.org/Journals/index.php/JLLL/article/view/42853/44147

Singh, R. (2018). Language change and directionality: A novel model for language change in Persian and Iranian languages from the sociolinguistic perspective. KAAV International journal of English, Literature, and linguistics, 5, 1-8. Retrieved from http://www.kaavpublications.org/journals/journal-5/article/article-1876.pdf

Singh, R. (2018). Mirroring Effects and the Water Code: A Cognitive-Semantic Approach to Natural Morphology in the Religious-Cultural Context. Journal of Literature, Languages and Linguistics, 46, 37-41. Retrieved from https://iiste.org/Journals/index.php/JLLL/article/download/43453/44769

Singh, R. (2018). Norwegian and Persian spatial prepositions: a novel comparative and syntactic approach to the 
spatial prepositions. KAAV international journal of English, literature, and linguistics, 5, 1-8. Retrieved from http://www.kaavpublications.org/journals/journal-5/article/article-1788.pdf

Singh, R. (2018). Persian Spatial Prepositions: A Novel Logical Syntactical Approach to the Spatial Prepositions. Studii şi cercetări filologice. Seria Limbi Străine Aplicate. Retrieved from http://scf-lsa.info/wp-content/uploads/2019/02/55-60-RAJDEEP-SINGH.pdf

Singh, R. (2018). Russian and Negative Prefixing: A Cognitive-Semantic Approach to the Negative Adjective Prefixing in Russian, Spanish, Persian, and English. English Linguistics Research, 7(4). https://doi.org/10.5430/elr.v7n4p7

Singh, R. (2019), Iran and Future European Union Gas Supply: Sociolinguistic Element of Iranian Gas Export Media Debate. English Linguistics Research, 8(3), 2019. https://doi.org/10.5430/elr.v8n3p1

Singh, R. (2019). Iranian Civil Rights Movement and Independence Movement in Kosovo? European Union's Role in the Freedom Movements and State-Building. English Linguistics Research, 8(1). https://doi.org/10.5430/elr.v8n1p8

Singh, R. (2019). Niedźwiedzia Przysługa? Bear's Favor? Hidden Garden behind the Concrete Proverbs: Cognitive-Semantic Analysis of Proverbs in Persian, Polish and Spanish. English Linguistics Research, 8(1). https://doi.org/10.5430/elr.v8n1p20

Singh, R. (2019). Rajdeep Singh, the Peace Poet: Analysis of Figurative Language Used in 'La paz que venga con fuerza' Poem by Rajdeep Singh. Journal of Literature, Languages and Linguistics, 53. https://doi.org/10.7176/JLLL

Sum, N. (2015). Towards a Cultural Political Economy: Staging an Encounter between Marx, Gramsci and Foucault. Paper presented at the inaugural closing keynote presentation, inaugural cultural political economy conference, Lancaster University, September 1-2. https://doi.org/10.5937/politeia0-20022

Van Dijk, T. A. (1993). Principles of critical discourse analysis. Discourse and Society, 4(2), 249-283. https://doi.org/10.1177/0957926593004002006

Van Dijk, T. A. (2015). Critical Discourse Studies: A Sociocognitive Approach. In Wodak, Ruth and Meyer, Michael (eds.), Methods for Critical Discourse Studies (pp. 62-86). London: Sage Publications. https://doi.org/10.1075/z.184.79dij

\section{Copyrights}

Copyright for this article is retained by the author(s), with first publication rights granted to the journal.

This is an open-access article distributed under the terms and conditions of the Creative Commons Attribution license (http://creativecommons.org/licenses/by/4.0/). 